\title{
Distribution of the Species Genus Scutellaria L. (Lamiaceae) Flora of the Ferghana Valley
}

\author{
Orzimat T. Turginov ${ }^{1}$, Mukhayyo H. Akbarova² \\ ${ }^{1}$ Institute of Botany of the Academy of Sciences of the Republic of Uzbekistan, Tashkent, Uzbekistan \\ ${ }^{2}$ Ferghana State University, Ferghana, Uzbekistan \\ Email: ozodbek88@bk.ru
}

How to cite this paper: Turginov, O.T. and Akbarova, M.H. (2020) Distribution of the Species Genus Scutellaria L. (Lamiaceae) Flora of the Ferghana Valley. American Journal of Plant Sciences, 11, 1533-1544. https://doi.org/10.4236/ajps.2020.1110111

Received: September 9, 2020

Accepted: October 9, 2020

Published: October 12, 2020

Copyright $\odot 2020$ by author(s) and Scientific Research Publishing Inc. This work is licensed under the Creative Commons Attribution International License (CC BY 4.0).

http://creativecommons.org/licenses/by/4.0/

\begin{abstract}
The article examines the representatives of the genus of Scutellaria L. distributed in the Ferghana Valley. On the basis of samples collected during field research and stored in the National Herbarium (TASH) Fund of the Institute of Botany Academy Sciences Republic of Uzbekistan, the growth of 23 species in the region was noted. Representatives of the genus Scutellaria L. are important due to the abundance of endemic species and their widespread use in modern pharmaceuticals. At the same time, opinions and comments on the study of natural resources of some species common in the valley are presented.
\end{abstract}

\section{Keywords}

Fergana, Valley, Species, Genus, Area, Herbarium, Flora, Endem

\section{Introduction}

The Fergana Valley is an intermountain lowland with an area of $22,000 \mathrm{~km}^{2}$ and $80,000 \mathrm{~km}^{2}$ of surrounding mountains. The valley is bounded on the northwest by Kurama and Chatkal, on the northeast by Fergana, and on the south by Turkestan and Alai. The valley consists mainly of plains [1]. According to the scheme of botanical-geographical regionalization of Uzbekistan, its mountainous areas are completely included in the Mountainous-Central Asian province and have three: Fergana, Fergana-Alai and Mogultag-Kurama districts. The part of the Fergana Valley belonging to the Republic of Uzbekistan corresponds to the Kurama, Chatkal and Alai ridges, and administratively to Namangan, Fergana and Andijan regions (Figure 1).

Transformation processes in ecosystems as a result of the impact of biotic, abiotic and anthropogenic factors on nature require greater attention to the study 


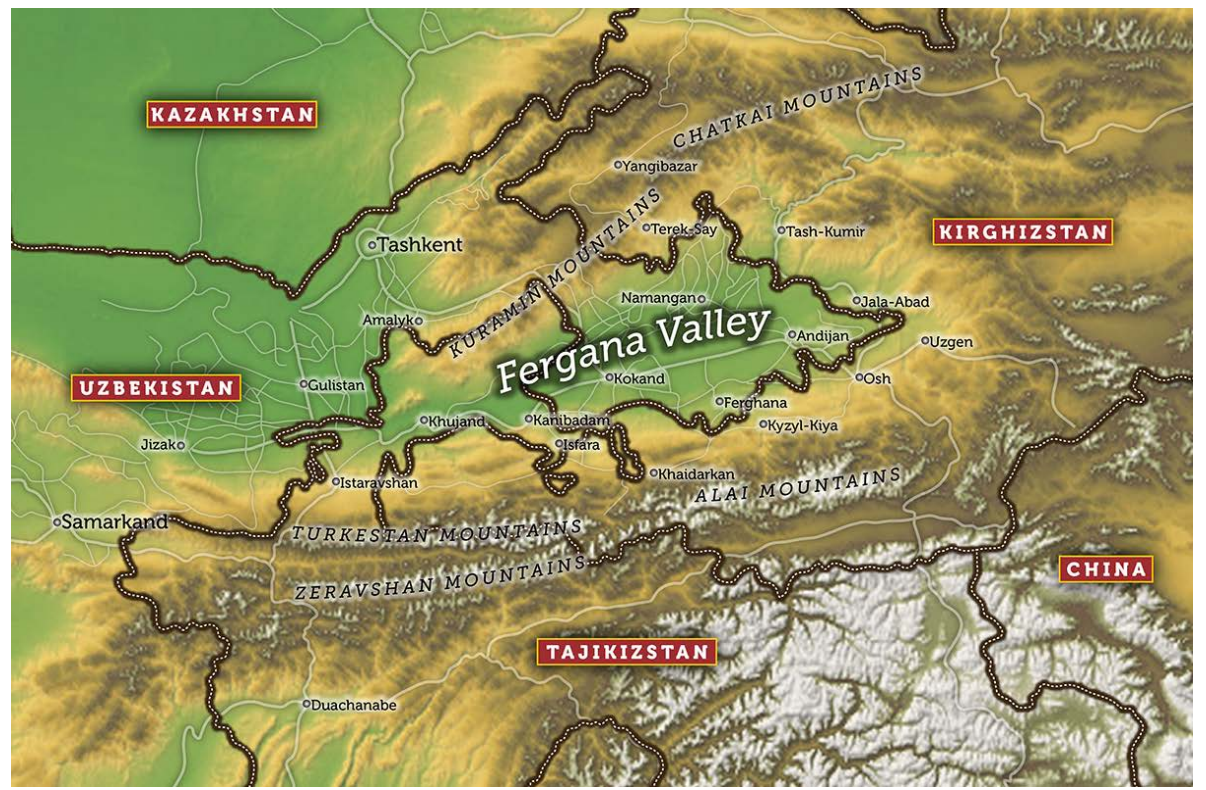

Figure 1. Map of the study area.

of local biodiversity, in particular, species identification and bio documentation of flora objects.

In recent years, there has been an increase in targeted research on the comprehensive study of local flora in Uzbekistan (Karimov, 2016; Batoshov, 2016; Turginov, 2017; Abduraimov, 2017; Azimova, 2018; Esanov, 2018, Akhmedov, 2018). As a result, the species composition of the regions, the state of the population of plants belonging to a particular group, natural resources and others are being studied. One such study is entitled "Bioecological features and resources of Scutellaria L. (Lamiaceae) species in the flora of the Fergana Valley". Another need for research on Scutellaria L. species is that in recent years chemists working in our country have been conducting research to study the chemical composition of Scutellaria L. species in the flora of Uzbekistan.

A.M. Karimov (2017) [2] and G.U. Siddikov (2018) [3] studied to isolate some species of Scutellaria L. distributed in the flora of Uzbekistan $S$. sordifrons Juz., S. phyllostachya Juz., S. comosa Juz., S. haematochlora Juz., S. immaculata Nevski ex Juz., $S$. ocellata Juz. and, for the first time, new flavonoids, glycosides, and aglycones. The biological activity of these substances, such as the alkaloids paracetamol and heliotrin, has been shown to have anti-inflammatory and anti-toxic, sedative, and antihypertensive effects, as well as the technology of dyeing half-wool, wool, silk and other fabrics. In doing so, scientists are gathering Scutellaria species directly from nature. Scientific substantiation of the order of collection of species from nature, identification and census of natural resources, assessment of the current state of ceonopopulations and development of recommendations for the preservation of gene pool in order to ensure future stability, mapping of species distribution and vitality, need protection. It is advisable to develop measures to preserve the natural populations of the species. 


\section{Object and Method}

Herbarium samples collected in field studies conducted in different regions of the Fergana Valley in 2019-2020, as well as the National Herbarium of Uzbekistan (TASH), the Herbarium Base of Moscow State University (MW) and the Herbarium Base of the Faculty of Biology of Samarkand State University used collected samples from 1913-2020. The distribution area and general area of the species was based on the "Conspectus florae Asia Mediae XI" (Abdullaeva, 1987) [4], Flora URSS XX (Yusepchuk, 1954) [5], Flora of Uzbekistan IV (Vvedensky, 1961). The names of the species are listed in the latest International Plants Names Index (http://www.ipni.org/) [6], the World Plants Catalog of Life (http://www.catalogueoflife.org/) [7], and the authors of the taxa are listed in the Authors of Plant Names R.K. Brummit, C.E. Powell's (1992) [8] manual. This work provides a general checklist of the genus of Scutellaria L. distributed in the flora the Fergana valley, using field research, the monograph "Labitae in flora of Kyrgyzstan" (2016) [9], existing dissertations, and the found herbariums. The list includes information on the first edition, ecology, economic importance, distribution and herbarium voucher collected from the valley.

\section{Result and Discussion}

Today, more than 350 species of Scutellaria L. are found on Earth (Farzaneh et al., 2020) [10]. This genus is widespread in the foothills and mountainous regions of Eurasia, where species diversity is higher than in other regions, especially Iran-Turan, Central Asia and Afghanistan, where the Mediterranean is considered to be one of the centers of origin. The eastern part of the sea is recognized as the second center (Safikhani, 2017) [11]. In the flora of URSS the genus species [5] into 4 sections: Euscutellaria Brig., Cystaspis Juz., Anaspis (Roching) Juz., Apeltanthus (Nevsky) Juz. and 148 species belonging to the genus were recorded. There are 84 species of the genus in Central Asia (Abdullayeva, 1987) [4]. Of these, 32 species are in the flora of Uzbekistan (Vvedensky, 1961) [12] (as a result of field research and taxonomic changes in recent years, 40 species of the genus are distributed in the flora of Uzbekistan (http://www.floruz.uz/)) [13]. Moreover, 15 species of these are found in the Uzbek part of the Fergana Valley. Our field research, which has been carried out directly in compiling the list of species identified in the Fergana Valley, herbarium materials in large collections, G.A.Lazkov's monograph "Labitae in flora of Kyrgyzstan” (2016) [10] and T.Kh. Khudoyberdiyev (1995) research work "Gubotsvetniye v rastitelnom pokrove Ferganskoy dolini” served as an crucial source.

T.Kh.Khudoyberdiyev (1995) [14] in "Gubotsvetniye v rastitelnom pokrove Ferganskoy dolini” in the Fergana Valley named 27 species of Scutellaria, but cited by the scientist Scutellaria oligodonta Juz., Scutellaria microphysa Juz., Scutellaria glabrata Vved., Scutellaria adsurgens Popov, Scutellaria microdasys Juz., Scutellaria leptosiphon Nevski, Scutellaria przewalskii Juz. and Scutellaria paulsenii Briq, which are found in areas not related to the Fergana Valley. How- 
ever, among the samples stored in the founds (MW, TASH, LE, FR, TAK) there are no samples collected from areas close to the valley. In addition is paid to the habitats of the species mentioned in the literature, $S$. oligodonta in the vicinity of the like Issyk-Kul, Terskay Alatav, Ketmantag, Kyrgyz Alatav, Talass Alatav, in the middle reaches of the basin of Narin rivern, $S$. paulsenii in the Alai valley, Eastern Pamir, S. microphysa in the Turkestan, Zaravschan and Gissar ridges of the Pamir-Alai, S. glabrata in the Turkestan, Nurata, Zaravschan and Gissar ridges of the Pamir-Alai, S. adsurgens in Karatag, Talass Alatav of Tien-Shan, Ugam, Qurama ridges, $S$. microdasys are found in the Talass Alatva, Kardjantau and Ugam ridges of Western Tien-Shan, S. leptosiphon in Zaravschan and Gissar ridges (Abdullayeva, 1987) [4].

According to T.Kh. Khudoyberdiev (1995) [14] S. oligodonta in the Fergana ridge, $S$. paulsenii in the Fergana and Alai ridges, $S$. microphysa in the Alai ridge, S. glabrata in Turkestan and mountain Mogultau, $S$. adsurgens in Turkestan and in the mountain Mogultau, S. microdasys in the Chatkal ridge, S. leptosiphon in the Alai ridge, but there is no herbarium specimen or any basis to confirm that the species occurs in these regions. However, recent literature and research have not reported any species in the Fergana Valley. As an example, K.SH. Tajibayev (2012) cited the occurrence of $S$. microdasys in the Kardjantau and Ugam ridges for the flora of Western Tien Shan, and $S$. adsurgens in the Kardjantag, Ugam, Pskam and Chatkal ridges.

G.A. Lazkov (2016) [9] cited S. paulsenii in the flora of Kyrgyzstan in the Dzungarian-Tien-Shan-Alai and Kashgar provinces. T.Kh.Khudoyberdiev's research is one of the main sources in our study of Scutellaria L. species in the Fergana valley. Our research field has shown that 23 species of Scutellaria L. are distributed in the flora of the Fergana valley in general, of which 15 species are distributed in the flora of Uzbekistan, and the remaining species are found in the flora of Kyrgyzstan and Tajikistan (Table 1).

Table 1. Distribution species Scutellaria L. in Ferghana Valley.

\begin{tabular}{|c|c|c|}
\hline № & Species & Distribution \\
\hline 1 & S.adenostegia Briq & $\begin{array}{l}\text { Western Tien-Shan and Pamir-Alai. Uzbekistan, Kyrgyzstan and } \\
\text { Tajikistan. }\end{array}$ \\
\hline 2 & $S$. galericulata L. & $\begin{array}{l}\text { Zaysan depression, Kazakhstan Upland, Balkhash deserts, } \\
\text { Turgai depression, Aral deserts, Bolshie Barsuki, Muyunkum, } \\
\text { Western Tien-Shan and Pamir-Alai ridges. Distributed } \\
\text { throughout the Holarctic }\end{array}$ \\
\hline 3 & S. ramosissima Popov & $\begin{array}{l}\text { Western Tien-Shan and Pamir-Alai. Uzbekistan, Kyrgyzstan, } \\
\text { Kazakhstan and Tajikistan. }\end{array}$ \\
\hline 4 & $S$. intermedia Popov & $\begin{array}{l}\text { Western Tien-Shan and Pamir-Alai. Uzbekistan, Kyrgyzstan and } \\
\text { Tajikistan. }\end{array}$ \\
\hline 5 & S. comosa Juz. & $\begin{array}{l}\text { Western Tien-Shan and Pamir-Alai. Uzbekistan, Kyrgyzstan and } \\
\text { Tajikistan. }\end{array}$ \\
\hline 6 & S. oxystegia Juz. & $\begin{array}{l}\text { Western Tien Shan, Pamir-Alai. Uzbekistan, Kyrgyzstan and } \\
\text { Kazakhstan. }\end{array}$ \\
\hline
\end{tabular}




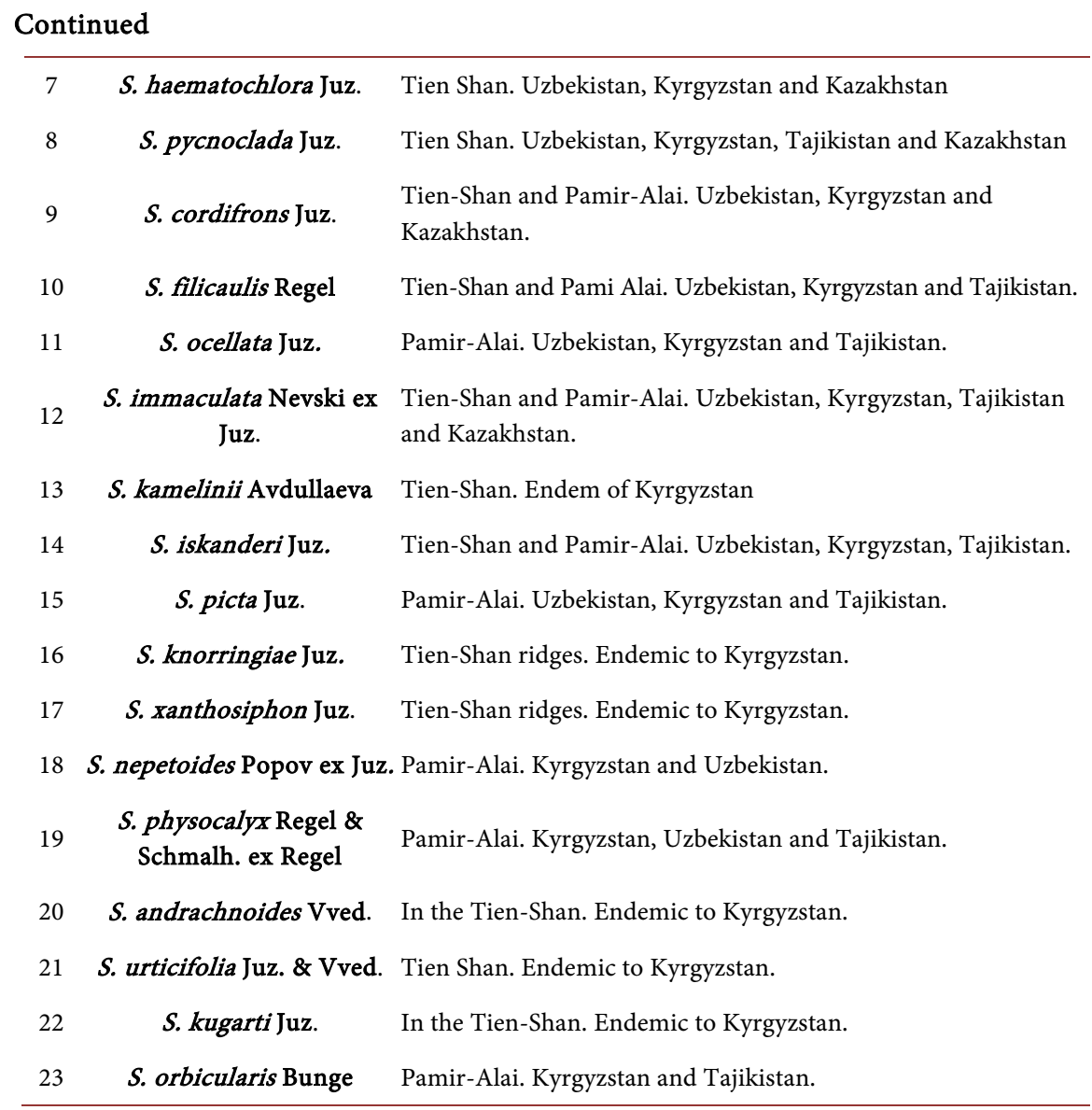

The most common species in the Fergana Valley are:

1) Scutellaria adenostegia Briq. 1907, Bot. Tidsskr. 28: 233.

Ecology: stony, gravelly, fine-earth slopes, rocks, talus, dry channels, red sandstones.

Distribution: Western Tien-Shan and Pamir-Alai. Uzbekistan, Kyrgyzstan and Tajikistan.

Herbarium data: Osh region, valley of the Tar river, 21.04.1981, Pimenov, Klyuikov, Vasilyeva, Tomkovich, Lavrova ${ }^{\circ} 577$; Northern slope of the Alai range, pass of Chokmak, 07.16.1981, Pimenov, Klyuikov, Vasilieva, Tomkovich, Lavrova $n^{\circ} 385$ (MW); Namangan region, Yangikurgan district, near vill. Alikhan, 07.29.1971, Rakhimova; Alai range, Shakhimardan, 10.06.1962, Shonazarov $\mathrm{n}^{\circ} 2640$ (TASH).

Significance: not used.

Our field studies have shown that the population of this species is distributed in the foothills of the Chodaksay basin and around the villages of Madaniyat and Chorkesar. The population has been declining as a result of the development of natural areas where the species grows.

2) Scutellaria galericulata L. 1753, Sp. Pl. 599.

Ecology: shores of water bodies, tugai, rice fields, damp places.

Distribution: Zaysan depression, Kazakhstan Upland, Balkhash deserts, Tur- 
gai depression, Aral deserts, Bolshie Barsuki, Muyunkum, Western Tien-Shan and Pamir-Alai ridges. Distributed throughout the Holarctic.

Herbarium data: Fergana Valley, Balykchy district In 1/4 to from Min-Bulak. 08.25.1935, Titov, Ioffe $\mathrm{n}^{\circ} 307$; basin of Chadaksay, 01.09.1994, Maltsev; Oz. Sary-Chelek, Khoja-Ata, 07.14.1971, Tsukervanik n ${ }^{\circ}$ 137; Valley of the Arslanbob river, 09.24.1942, Tuychiev (TASH).

Significance: medicinal, essential oil, dyeing, honey plant.

3) Scutellaria ramosissima Popov 1924, Bot. Mater. Gerb. Glavn. Bot. Sada RSFSR 5: 155.

Ecology: rocky, gravelly slopes, talus, dry channels.

Distribution: Western Tien-Shan and Pamir-Alai. Uzbekistan, Kyrgyzstan, Kazakhstan and Tajikistan. According to literary and other sources, there is no information on the occurrence of this species in the flora of Tajikistan. Among the samples stored in the founds, there are samples collected from the flora of Tajikistan. (Gissar Ridge Iskenderkul, 07.08.1976, Klyuikov, Vasilyeva, Baronova $\mathrm{n}^{\circ} 1012$ (MW); Kuraminskiy ridge, Altyn-Topkan mountains, 06.18.1953, Vernik, Nabiev, Tsukervanik n 360 (TASH). These identified herbarium specimens indicate that this species is also found in the flora of Tajikistan, which is considered a scientific curiosity.

Herbarium data: Jalalabad region, basin of Narin, Karasu, 22.06.2000, Pimenov, Klyuikov, Lazkov n 34 (MW); Eastern Fergana, Chatkal region, 08.02.1927, Sovetkin $n^{\circ} 1051$ (TASH).

Significance: not used.

4) Scutellaria intermedia Popov 1926, Bull. Sred.-Aziat. Gosud. Univ. 12:16.

Ecology: stony, gravelly slopes, rocks, pebbles.

Distribution: Western Tien-Shan and Pamir-Alai. Uzbekistan, Kyrgyzstan and Tajikistan.

Herbarium data: Mogoltau mountains, 05.12.1967. Pavlov n 34 (MW).

Significance: not used.

5) Scutellaria comosa Juz. 1951, Bot. Mater. Coat of arms. Bot. Inst. Komarova Acad. Nauk S.S.S.R. 14: 381.

Ecology: gravelly, fine-grained soils, rock crevices.

Distribution: Western Tien-Shan and Pamir-Alai. Uzbekistan, Kyrgyzstan and Tajikistan.

Herbarium data: hills around Damkol village, Fergana district, Fergana region, N 40³1'39.67"; E 71²0'83.53", h-685m. 24.05.2019, Akbarova; Hills around Zilol sanatorium on the outskirts of Chimgan village, Fergana district, Fergana region, N $40^{\circ} 28^{\prime} 02.88^{\prime \prime}$; E 71 52'98.51", h-580m. 19.05.2019, Akbarova; Around the village of Gova, Chust district, Namangan region, N 41 '15'38.13"; E 71 09'69.25". 12.06.2019, Akbarova; Turakurgan-Kasan road, Gozalobod village, Turakurgan district, N $41^{\circ} 02^{\prime} 66.23^{\prime \prime}$; E 71 ${ }^{\circ} 50^{\prime} 77.26^{\prime \prime}$. 16.05.2020, Turginov, Akbarova; Pop district Culture village, N 41 00'74.69"; E 7093'76.70". 16.05.2020, Turginov, Akbarova. Imam-Ota mountain range, Khojaabad district, Andijan region, $\mathrm{N}$ 4056'37.43"; E 7261'02.74" 15.06.2019, Akbarova (TASH). 
Significance: According to the literature, this species is not used in agriculture. According to the ethnobotanical data of our study areas, the above-ground parts collected during the flowering period of the species are said to be used as a tincture in the improvement of digestive and circulatory organs, in infirmity and anemia. In recent years, chemists working in our country have isolated new flavonoids, glycosides and aglycones in the species. The biological activity of these substances, such as paracetamol and heliotrin alkaloids, has been shown to have anti-inflammatory, sedative, antihypertensive effect, as well as the technology of dyeing half-wool, wool, silk and other fabrics. (Karimov (2017) [2] and G.U. Siddikov (2018) [3]. With this in mind, the inventory of the species' natural resources is important for the conservation of the species's gene pool.

6) Scutellaria oxystegia Juz.1939, Bot. Zhurn. S.S.S.R. 24: 431.

Ecology: on stony, stony-fine-earth slopes.

Distribution: Western Tien Shan, Pamir-Alai. Uzbekistan, Kyrgyzstan and Kazakhstan.

Herbarium data: Fergana. Steep slopes of adyrs near Izbaskent, 05.19.1916, Rozanov n085; Fergana Valley $8-10 \mathrm{~km}$ south of the villages. Tashkumyr. Adyry, 05.21.1952 Arifkhanov ${ }^{\circ}$ 785; Pamir-alai. Alai ridge, the vicinity of the village. Vuadil, 05.08.1965, Shonazarov ${ }^{\circ}{ }^{\circ} 1461$; On the way from Dzhida-Bulak to Tashkumyr, 07.24.1949, Chevrenidi ${ }^{\circ}$ 1044; Fergana ridge. Western slope. 2 $\mathrm{km}$ to the northeast from the k.k Gava. Southern slope descending to Gava-say, 07.24.1938, Demurina ${ }^{\circ}$ 197; Fergana region $8 \mathrm{~km}$ south of st. Vannovsky on adyrs, 06.03.1949, Sakhobiddinov, Li n 187 ; (TASH).

Significance: alkaloid, essential oil, honey plant.

7) Scutellaria haematochlora Juz. 1951, Bot. Mater. Coat of arms. Bot. Inst. Komarova Acad. Nauk S.S.S.R. 14: 408.

Ecology: on stony, stony-fine-earth slopes.

Distribution: Tien Shan. Uzbekistan, Kyrgyzstan and Kazakhstan.

Herbarium data: Chatkal ridge, vicinity of the lake. Sary-Chilek. 07.14.1962, Pyataeva, Arifkhanova n ${ }^{\circ} 371$; Chatkal Range, env. Lake Sary-Chelek, 17.07.1962, Tsukervanik $\mathrm{n}^{\circ} 764$; South-East. Chatkal Ridge Jalalaabad region Karavan district, 06.10.1955, Belenovskaya(TASH).

Significance: not used.

8) Scutellaria pycnoclada Juz. 1951, Bot. Mater. Coat of arms. Bot. Inst. Komarova Acad. Nauk S.S.S.R. 14: 411.

Ecology: on rocky and gravelly slopes.

Distribution: Tien Shan. Uzbekistan, Kyrgyzstan, Tajikistan and Kazakhstan.

Herbarium data: River basin Chadak, env. Kandagan, lower mountain belt, 05.15.2010 Tojibaev, Students; $19 \mathrm{~km}$ north of Papa on the road to Dzharkatan, 05.05.1949, Bondarenko, Mailun; Eastern Fergana, Kyzyl-Dzhar region. Cassansu steppe slope, 20.09.1927, Abolin n ${ }^{\circ} 792$; Valley of the Chatkala River, 12.07.1927, Abolin n²88; Papal district, env. village Mazar sai Uryukli. 06.13.1949, Bondarenko ${ }^{\circ} 158$ (TASH).

Significance: not used. 
9) Scutellaria cordifrons Juz. 1951, Bot. Mater. Coat of arms. Bot. Inst. Komarova Acad. Nauk S.S.S.R.14: 363.

Ecology: on stony, gravelly slopes, on rocks, stony placers.

Distribution: Tien-Shan and Pamir-Alai. Uzbekistan, Kyrgyzstan and Kazakhstan.

Herbarium data: Southern Kyrgyzstan. Arslanbob. Upper reaches of the Arslanbob river, subalpine belt. 09.24.1942, Tuychiev, (Turkestan ridge), Chatkal, Kurama), Namangan, Yangikurgan region, Nanai village, Turbaza, 05.10.2020, Turginov (TASH).

Significance: Scutellaria cordifrons contains essential oils, phenolic compounds, flavonoids, and polysaccharides. Baikalein-6-ObD-glucuronide, 5,8-dihydroxy-6,7dimethoxyflavone, norvogonin-7-O-D-glucopyranoside were isolated from the underground part of the plant, which is widespread around the variegated summit of the slopes of Mount Kurama, near the Chust region, Namangan region., norvogonin-7-O-glucuronide, rivularin, dimethoxyflavone substances, and polysaccharides (water-soluble polysaccharides, pectin, hemicelluloses) were isolated from the plant surface. Currently, drugs based on polysaccharides are used in medicine: blood substitutes polyglucin, rheopolyglucin, anticoagulant-heparin, expectorant-mucaltin, gastrointestinal drugs-plantaglucid. This is a potential source for the development of new dietary supplements and drugs based on polysaccharides.

10) Scutellaria filicaulis Regel 1882, Izv. Imp. Obsc. Ljubit. Estesv. Moskovsk. Univ. 34(2): 69.

Ecology: rocky slopes, rocks, talus.

Distribution: Tien-Shan and Pami Alai. Uzbekistan, Kyrgyzstan and Tajikis$\tan$.

Herbarium data: Kokand, pass of Kavuk 24.VII.1881, O. Fedchenko (LE); Osh district, basin of river Isfayram. 09.10.1930, Titov n ${ }^{\circ} 152$ (TASH).

Significance: not used.

11) Scutellaria ocellata Juz. 1951, Bot. Mater. Coat of arms. Bot. Inst. Komarova Acad. Nauk S.S.S.R.14: 376.

Ecology: Fine-earth, gravelly slopes.

Distribution: Pamir-Alai. Uzbekistan, Kyrgyzstan and Tajikistan.

Herbarium data: A spare part of the Alai range. the village of Jordan, 06.10.1965, Shonazarov ${ }^{\circ}$ 1480; Alai ridge, Shakhimardan village, 06.22.1968, Khudaiberdiev (TASH).

Significance: Pharmacological studies have identified compounds with high gastroprotective and anti-inflammatory activity among the isolated flavonoids. It is recommended to use the aerial part of the $S$. ocellata plant, which retains the flavonoid cinaroside, which has a high hypoazotemic effect.

12) Scutellaria immaculata Nevski ex Juz. 1951, Bot. Mater. Coat of arms. Bot. Inst. Komarova Acad. Nauk S.S.S.R. 14: 428.

Ecology: stony, gravelly slopes, rocks, pebbles.

Distribution: Tien-Shan and Pamir-Alai. Uzbekistan, Kyrgyzstan, Tajikistan 
and Kazakhstan.

Herbarium data: Western part of the Alai ridge near the village. Shakhimardan. 06.10.1964, Shonazarov n ${ }^{\circ} 241$; Alai ridge, Shakhimardan, 06.08.1947, Shafeev; Alai Ridge, basin of Shakhimardan, 15.07.1957, Soskov; Western part of the Alai ridge, Shakhimardan, 10.06.1964, Shonazarov n ${ }^{\circ} 241$; Shakhimardan village, Fergana region Northern ridges of the Shakhimardansay basin, N 3996'5395; E $71^{\circ} 75^{\prime} 9803$, h-1134. 06.05.2019, Akbarova. Yordan village, Fergana region, northern slopes of the Aksu river. 06.06.2019, Akbarova. Sokh region basin of the Sokh river slopes of mountain Demursat, N 39 56.07.1"; E 71 10.59.3", h-1886. 05.25.2019, Akbarova. (TASH).

Significance: A.M. Karimov isolated 25 flavonoids of a known chemical structure from $S$. immaculata, including 22 flavonoids (10 free aglycones and 12 glycosides), 2 flavanones, and 1 flavonol, including an immunaculoside from $S$. immaculata, and a method was developed for the separation of the flavonoids of wogonin-7-O- $\beta$-D-glucopyranoside. Pharmacological studies have identified compounds with high gastroprotective and anti-inflammatory activity among the isolated flavonoids.

13) Scutellaria kamelinii Avdullaeva 1994, Dokl. Acad. Science Rep. Uzbek. 1994(9): 48.

Ecology: stony, gravelly slopes, pebbles.

Distribution: Tien-Shan. Endem of Kyrgyzstan.

Herbarium data: Fergana Valley and Chatkal ridge, the valley of the river. Pashsha-Ata. 08.14.1936, Skorokhodov, Azatyan n²13 (TASH).

Significance: not used. This species was introduced into science by M.N. Abdullaeva. Instances of this species are currently kept in the National Herbarium of Uzbekistan. A.G. Lazkov's monograph "Labitae in flora of Kyrgyzstan" is not cited.

14) Scutellaria iskanderi Juz. 1951, Bot. Mater. Coat of arms. Bot. Inst. Komarova Acad. Nauk S.S.S.R. 14: 410.

Ecology: On stony, stony-gravelly slopes.

Distribution: Tien-Shan and Pamir-Alai. Uzbekistan, Kyrgyzstan, Tajikistan.

Herbarium data: Neighborhoods of village Chadak on the slope of the hills, 11.06.1949, Chevrenidi ${ }^{\circ} 140$ (TASH).

Significance: Scutellaria iskanderi contains biologically active substances: tannins, phenolic compounds, flavonoids, coumarins, proteins, macro- and microelements, a new antihypertensive and sedative phytopreparation based on plants, tortuosin-coumarin, is standardized as a tincture.

The only collected specimen of this species is kept in the found National Herbarium of Uzbekistan. In recent years, research in the valley has not collected specimens of this species.

15) Scutellaria picta Juz. 1951, Bot. Mater. Coat of arms. Bot. Inst. Komarova Acad. Nauk S.S.S.R. 14: 393.

Ecology: On stony-gravelly slopes in the middle and upper belt mountains.

Distribution: Pamir-Alai. Uzbekistan, Kyrgyzstan and Tajikistan. 
Herbarium data: Fergana region: Sary-tau mountains. 06.24.1920, Popov n ${ }^{\circ} 631$; Pamir-alai. Alai ridge. Lake Kurban-kul 14.06.1967, Khudaiberdiev; Pamir-alai. Alai ridge, Yardan, 17.07.1967, Khudaiberdiev (TASH).

Significance: not used. According to M.N. Abdullaeva (1987), this species is not found in the flora of Uzbekistan and Kyrgyzstan. Later G.A. Lazkov, B.A. Sultanova (2011) [15] cited in the monograph "Checklist of vascular plants of Kyrgyzstan". According to the samples stored in the founds, it was established that this species is also widespread in the flora of Uzbekistan.

16) Scutellaria knorringiae Juz. 1951, Bot. Mater. Coat of arms. Bot. Inst. Komarova Acad. Nauk S.S.S.R. 14:366.

Ecology: On the slopes and gorges, on rocky talus on average.

Distribution: Tien-Shan ridges. Endemic to Kyrgyzstan.

Herbarium data: Fergana prov., Namangan dist., Aflatun, 26.VI.1912, Knorring n`366 (LE); lake of Sary-Chelek, southern slopes of the watershed, 07.22.1962, Tsukervanik n ${ }^{\circ} 866$ (TASH).

Significance: not used.

17) Scutellaria xanthosiphon Juz. 1951, Bot. Mater. Coat of arms. Bot. Inst. Komarova Acad. Nauk S.S.S.R. 14:367.

Ecology: Subalpine meadows in the upper belt of the mountains.

Distribution: Tien-Shan ridges. Endemic to Kyrgyzstan.

Herbarium data: Jalal abad prov., Karat, 11.VI.1945, Whipper (LE);

Significance: not used.

18) Scutellaria nepetoides Popov ex Juz. 1951, Bot. Mater. Coat of arms. Bot. Inst. Komarova Acad. Nauk S.S.S.R. 14: 395.

Ecology: On stony-gravelly slopes.

Distribution: Pamir-Alai. Kyrgyzstan and Uzbekistan.

Herbarium data: Fergana prov., northern slope of the Alai range, basin of Shahimardan, 3.VIII.1915, Drobov (LE); Alai range basin of river Shakhimardan, valley Kok-su, 19.07.1962, Pyataeva, Arifkhanova n ${ }^{\circ} 168$ (TASH).

Significance: A.M. Karimov isolated 25 flavonoids of known chemical structure from S. nepetoides, including 22 flavonoids (10 free aglycones and 12 glycosides), 2 flavanones, and 1 flavonol, including nepetoside A from $S$. immaculata, and a method for the separation of 5,8-dihydroxy-7-O-D-galacturonidopyranosylflavone nepetoside A was developed. Pharmacological studies have identified compounds with high gastroprotective and anti-inflammatory activity among the isolated flavonoids.

19) Scutellaria physocalyx Regel \& Schmalh. ex Regel 1882, Izv. Imp. Obsc. Ljubit. Estesv. Moskovsk. Univ. 34(2): 68.

Ecology: stony, gravelly slopes, rocks, talus.

Distribution: Pamir-Alai. Kyrgyzstan, Uzbekistan and Tajikistan.

Herbarium data: Kokan k., Alai, 22 VII 1871, O. Fedchenko (LE); Alai ridge, on the top of the pass of Taldyk, 08.22.1923, Raikova $n^{\circ} 168$ (TASH).

Significance: not used.

20) Scutellaria andrachnoides Vved. 1954, Fl. URSS 20: 514. 
Ecology: Rocks in the foothills.

Distribution: In the Tien-Shan. Endemic to Kyrgyzstan.

Herbarium data: Jalalabad region, basin of river Narin, Karasu, 22.06.2000, Pimenov, Klyuikov, Lazkov n 43 (MW); Eastern Fergana. Kyzyl-Dzhar district, basin of river Narin, Ish-say, 09.10.1927, Abolin n686 (TASH).

Significance: not used.

21) Scutellaria urticifolia Juz. \& Vved. 1954, Fl. URSS 20: 510.

Ecology: On clay-gravel soil in the foothills.

Distribution: Tien Shan. Endemic to Kyrgyzstan.

Herbarium data: Fergana ridge, near vill. Gava, 07.06.1928, Kryltsova ${ }^{\circ} 101$ (TASH).

Significance: not used.

22) Scutellaria kugarti Juz. 1951, Bot. Mater. Coat of arms. Bot. Inst. Komarova Acad. Nauk S.S.S.R.14: 371.

Ecology: Grassy slopes in the upper belt of the mountains.

Distribution: In the Tien-Shan. Endemic to Kyrgyzstan.

Herbarium data: Fergana range. per. Caldam, alt. $2800 \mathrm{~m}$ asl, 01.08.1962, Pryakhin, Muydinova (TASH).

Significance: not used.

23) Scutellaria orbicularis Bunge 1851, Mém Sav. Étr. Acad. Petersb. 7: 436.

Distribution: Pamir-Alai. Kyrgyzstan and Tajikistan.

Herbarium data: Fergana region, Isfara, 20.04.1901, Lipsky n ${ }^{\circ} 41$ (MW).

Significance: not used.

\section{Conclusions}

The peculiarity of the study of the species distributed in the valley is that in recent years, there has been an increase in research on the chemical composition of many species in the region, the abstraction of species as a result of irregular collection of biologically active substances, the relative obsolescence of existing data, targeted floristic studies of flora in the region and is not confirmed by herbarium specimens of the species listed. Research field, literature and analysis of samples stored in the founds revealed for the first time that 23 species of the genus Scutellaria L. were recorded in the flora of the Fergana valley.

All of the identified species were confirmed by herbarium specimens. Of these 23 species, 6 species are found in the flora of Kazakhstan and 11 species in the flora of Tajikistan. All 23 species spread to the flora of Kyrgyzstan, of which 6 species are endemic to Kyrgyzstan. Out of 23 species, 15 species are distributed in the flora of Uzbekistan. Of these 15 species: $S$. adenostegia, S. comosa, S. immaculate and $S$. ramosissima have been observed in field studies leading to a wider distribution than other species. These include $S$. adenostegia and $S$. comosa. The inventory of the natural resources of these species and the study of their population status will be essential in maintaining the gene pool of the species in the future. 


\section{Conflicts of Interest}

The authors declare no conflicts of interest regarding the publication of this paper.

\section{References}

[1] (2005) National Encyclopedia Uzbekistana IX Tomus. National Encyclopedia of Uzbekistan State Scientific Publishing, Tashkent, 47.

[2] Karimov, A.M. (2017) Flavanoids of 4 Plants That Are the Member of the Scutellaria L. Specie Growing in Uzbekistan. Dis. Cand. Biol. of Sciences, Tashkent, 4.

[3] Siddikov, G.U. (2018) Second Metabolits of Plants S. phyllostachya and $S$. cordifrons, Member of the Species Scutellaria L. Growing in Uzbekistan: Separation, Chemical Structure and Biological Activity. Dis. Cand. Biol. of Sciences, Ferghana, $24 \mathrm{p}$.

[4] Abdullaev, M.N. (1987) Genus of Scutellaria L.-Shlemnik. In: Conspectus Florae Asiae Mediae, Fan, Tashkent, Vol. IX, 13-37.

[5] Yusepchuk, S.V. (1954) Genus Scutellaria L.-Shlemnik. Flora URSS. Moskva-Lelingrad. Academiae Scientiarum URSS, 20, 72-198.

[6] The Plant List [Electronic Resource]. http://www.theplantlist.org

[7] The World Plants Catalog of Life [Electronic Resource]. http://www.catalogueoflife.org

[8] Brummit, R.K. and Powell, C.E. (1992) Authors of Plant Names. 102 p.

[9] Lazkov, G.A. (2016) Labitae in Flora of Kyrgyzstan. Korea National Arboretum, Pocheon, 384 p.

[10] Dehkordi, F.J., Kharazian, N. and Lorigooin, Z. (2020) Characterization of Flavonoid Components in Scutellaria L. Species (Lamiaceae) Using Fingerprinting Analysis. Acta Biologica Cracoviensia Series Botanica, 62, 79-96.

[11] Safikhani, Z.J. and Saeidi, H. (2017) Taxonomic Revision of Scutellaria multicaulis (Lamiaceae) Species Complex in Iran'. Iranian Journal of Botany, 23, 10-24.

[12] Vvedensky, A.I. (1961) Genus Scutellaria L.—Shlemnik. Flora Uzbekistanica. Tashkent. Academiae Scientiarum UzSSR, 10, 270-285.

[13] Floruz.uz [Electronic Resource]. http://www.floruz.uz

[14] Khudoyberdiyev, T.Kh. (1995) Gubotsvetniye v rastitelnom pokrove Ferganskoy dolini. Dis. Doctor. Biol. of Sciences, Tashkent, 24 p.

[15] Lazkov, G.A. and Sultanova, B.A. (2011) Checklist of Vascular Plants of Kyrgyzstan. Norrlinia Vol. 24, 1-166. 